\title{
Ebola: Towards an International Health Systems Fund
}

Lawrence O. Gostin

This paper can be downloaded free of charge from:

https://scholarship.law.georgetown.edu/facpub/1371

http://ssrn.com/abstract=2491758

Lawrence O. Gostin, Ebola: Towards an International Health Systems Fund, The Lancet, published Online First (September 4, 2014), http://download.thelancet.com/flatcontentassets/ pdfs/S0140673614613453.pdf

This open-access article is brought to you by the Georgetown Law Library. Posted with permission of the author. Follow this and additional works at: https://scholarship.law.georgetown.edu/facpub

Part of the Health Law and Policy Commons, Health Policy Commons, International Law Commons, International Public Health Commons, and the Public Policy Commons 


\section{Ebola: towards an International Health Systems Fund}

The international response to the current outbreak of Ebola virus in west Africa, which is projected to infect about 20000 people with a case fatality rate of more than $50 \%,{ }^{1,2}$ has been fractured and delayed. The index case (a 2-year-old boy from Guinea) died in December, 2013, followed by confirmed Ebola clusters on March 22, 2014, which quickly spread to Liberia and then Sierra Leone. The disease jumped to Nigeria through air travel, and, recently, to Senegal. Yet WHO did not declare a Public Health Emergency of International Concern (PHEIC) until Aug 8, 2014, and only released an Ebola response roadmap on Aug 28-5 months after international spread. ${ }^{2}$ WHO must now raise funds to implement the roadmap, which will further delay a robust international response. This tragedy could have been averted and, with more than 20 outbreaks of Ebola since 1976, the need for public health preparedness should have been foreseen.

This is the first Ebola outbreak to engulf major urban areas, with intense patterns of transmission. If the affected countries had adequate public health systems that were able to rapidly identify cases, trace contacts, and isolate infected and exposed patients, they probably would have contained Ebola within rural settings. The countries most affected by Ebola, however, rank lowest in global development, lacking essential public health infrastructure, the most basic of which is an adequate health workforce. WHO estimates a shortage of $7 \cdot 2$ million doctors, nurses, and midwives globally, ${ }^{3}$ with the countries most affected by Ebola among the worst off.

The crisis has depleted affected countries of their already scarce human resources: more than 130 health workers have died from Ebola. ${ }^{4}$ Even before the loss of lives, Liberia and Sierra Leone had only about 90 and 136 doctors, respectively. ${ }^{5.6}$ Liberia would need the present number of skilled health professionals to increase by about ten times-in Sierra Leone's case by nearer 20 times-to meet even a minimum threshold for an adequate health workforce. ${ }^{3.7}$ Guinea is only marginally better off, with fewer than 1000 doctors for a population of more than 11 million people. The loss of nurses, too, will have long-term repercussions. At one Sierra Leone hospital, for example, 15 nurses have died among 22 total health workers, ${ }^{8}$ with only three nurses avoiding infection; the country barely had 1000 nurses before the outbreak. ${ }^{6}$
Hospitals in affected countries have become amplification points for transmission, since they do not have rigorous infection control, personal protective equipment, and safe or sterile isolation facilities. Consequently, fearful patients have avoided hospitals, thus spreading Ebola infection in the community with individuals left untreated for myriad other health hazards, ranging from malaria and chronic disease to childbirth. ${ }^{9,10}$ Community health workers similarly fear Ebola, often refusing to examine patients and collect blood and urine samples.

The health infrastructure needed to prevent an initial outbreak from burgeoning out of control-precisely what has happened-remains out of the reach of low-income countries. The affected states do not have adequate community, laboratory, public health, and clinical personnel; infection-control equipment, supplies, and protocols; health worker training; laboratory facilities with high biosafety capabilities; health facilities, including safe isolation units; and communication systems that can effectively deliver important public health information. Affected countries have instead often resorted to military-led cordon sanitaires to separate large segments of the population without ensuring access to basic necessities, such as food, clean water, and health care.

The failure to build health-system capacity violates the 2005 International Health Regulations (IHR), ${ }_{1}^{11}$ which require countries to develop capabilities to detect, assess, report, and respond to global health emergencies.

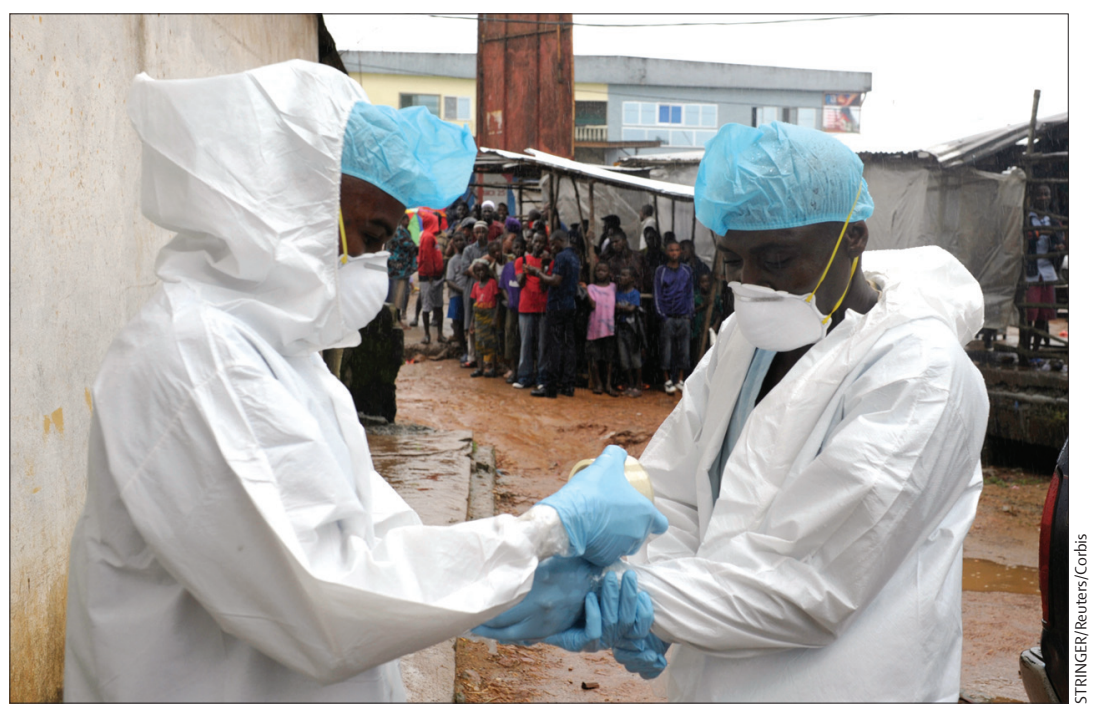

Published Online September 4, 2014 http://dx.doi.org/10.1016/ S0140-6736(14)61345-3 
196 states are parties to the IHR, yet many still do not possess the requisite core health-system capacities. Article 44 of the IHR requires states to mobilise financial resources and provide technical and logistical support to develop, strengthen, and maintain public health capacity. Yet WHO has no dedicated funds for IHR capacity building, with high-income countries failing to meet their IHR obligations to help build health systems.

Despite an increasing number of deaths and regional spread of Ebola in west Africa, a major international response did not occur until two American aid workers and a Spanish Priest became infected; even then, public attention was diverted by ethical concerns over the compassionate use of experimental drugs for Ebolaendorsed by WHO on Aug 11. However, drugs that have never been tested for safety in human beings, and are in extremely scarce supply, could never have contained the outbreak. Although development of effective vaccines and treatments for Ebola should be a global priority, the Ebola crisis could offer a unique opportunity to transform international health assistance towards sustainable health systems. Weak health systems represent an enduring and systemic problem not only for global health security, but also for the prevention and control of diseases across the spectrum-both infectious and non-communicable.

How could this Ebola outbreak have been averted and what could states and the international community do to prevent the next epidemic? The answer is not untested drugs, mass quarantines, or even humanitarian relief. If the real reasons the outbreak turned into a tragedy of these proportions are human resource shortages and fragile health systems, the solution is to fix these inherent structural deficiencies. A dedicated International Health Systems Fund at WHO would rebuild broken trust, with the returns of longer, healthier lives and economic development far exceeding the costs. This fund would encompass both emergency response capabilities and enduring health-system development.

WHO's Ebola response roadmap ${ }^{2}$ estimates that an initial US\$490 million in global resources over 6 months would be needed to curb the outbreak, although the total costs are likely to be considerably higher. Yet in 2011 a WHO Review Committee on the Functioning of IHR proposed the establishment of a Global Health Emergency Workforce, backed by a $\$ 100$ million contingency fund for surge capacity to be mobilised for a declared PHEIC. ${ }^{12} \mathrm{~A}$ well designed emergency workforce should comprise trained health professionals with experience in low-resource settings prepared for rapid deployment, and coordinated by WHO in partnership with national governments.

If contingency funding were in place, WHO would have had a strong incentive to declare an international emergency in a timely way. WHO did not, however, act on the Review Committee's recommendations, even though the proposed surge capacity fund would be affordable-representing less than $0.5 \%$ of international health assistance. ${ }^{13}$ WHO itself, which is plagued by severe financial troubles at a time of reform with no control over two-thirds of its budget, is not in a position to develop the fund in the absence of financial commitments from high-income states. ${ }^{14}$

A dedicated International Health Systems Fund would build national capacities not only to respond rapidly to public health emergencies, but also to enable low-income and some middle-income countries to deliver comprehensive health services. Governments themselves would be expected to allocate domestic funds, and fulfil the 2001 Abuja Declaration pledge by African heads of state to allocate at least $15 \%$ of national budgets to the health sector. A sustainable International Health Systems Fund would help low-income and some middle-income countries to build capacity to serve their entire populations.

The scale of a sustainable International Health Systems Fund, however, would require multibillion dollar investment channelled to low-income countries, thus mobilising the resources envisioned in the IHR, together with a right-to-health-based universal health coverage. Although the scale of investment would be substantial, political support could be marshalled with social mobilisation, just as occurred with AIDS through the US President's Emergency Plan for AIDS Relief (PEPFAR) and the Global Fund to Fight AIDS, Tuberculosis and Malaria. ${ }^{15}$

The west African Ebola epidemic could spark a badly needed global course correction that would favour strong health infrastructure. Sustainable funding scalable to needs for enduring health systems is a wise and affordable investment. It is in all states' interests to contain health hazards that may eventually travel to their shores. But beyond self-interest are the imperatives of health and social justice-a humanitarian response that would work, now and for the future. 


\section{Lawrence O Gostin}

O'Neill Institute for National and Global Health Law, Georgetown University Law Center, Washington, DC 20001, USA gostin@law.georgetown.edu

LOG is Director of the World Health Organization Collaborating Center for Public Health Law and Human Rights.

1 Centers for Disease Control and Prevention. 2014 Ebola outbreak in west Africa (Guinea, Liberia, Sierra Leone, and Nigeria). 2014. http://www.cdc. gov/vhf/ebola/outbreaks/guinea/index.html (accessed Sept 3, 2014).

2 WHO. Ebola response roadmap. Geneva: World Health Organization, 2014.

3 Global Health Workforce Alliance, WHO. A universal truth: no health without a workforce. Geneva: World Health Organization, 2014 http://www.who.int/workforcealliance/knowledge/resources/GHWA-a_ universal_truth_report.pdf?ua=1 (accessed Sept 2, 2014).

4 NPR. Ebola outbreak takes toll on Africa's health workers. Sept 1, 2014 http://www.npr.org/2014/09/01/345044302/ebola-outbreak-takes-tollon-africas-health-workers (accessed Sept 3, 2014).

5 Siedner MJ, Kraemer J. The global response to the Ebola fever epidemic: what took so long? PLOS Medicine blog, Augt 22, 2014. http://blogs.plos. org/speakingofmedicine/2014/08/22/global-response-ebola-feverepidemic-took-long/ (accessed Aug 30, 2014).

6 WHO. Global Health Observatory Data Repository: absolute numbers data by country. 2014. http://apps.who.int/gho/data/node.main. A1443?lang=en\&showonly=HWF (accessed Aug 30, 2014).

7 WHO. Global Health Observatory Data Repository: welcome to health workforce statistics. 2014. http://apps.who.int/gho/data/node.main. HWF?lang=en (accessed Sept 1, 2014).
8 Nossiter A, Solomon BC. If they survive in Ebola ward, they work on. The New York Times, Aug 24, 2014. http://www.nytimes.com/2014/08/24/ world/africa/sierra-leone-if-they-survive-in-ebola-ward-they-work-on. html (accessed Sept 2, 2014).

9 O'Carroll L. Ebola cases in west Africa could rise to 20,000 says WHO The Guardian, Aug 28, 2014. http://www.theguardian.com/society/2014/ aug/28/ebola-cases-rise-20000-world-health-organisation-west-africadeath-toll (accessed Sept 2, 2014).

10 Harris R. Why Ebola is making it harder to provide good health care. National Public Radio blog, Aug 21, 2014. http://www.npr.org/blogs/ goatsandsoda/2014/08/21/342228828/why-ebola-is-making-it-harderto-provide-good-health-care (accessed Sept 2, 2014).

11 WHO. International Health Regulations (2005) second edition. Geneva: World Health Organization, 2008.

12 WHO. Implementation of the International Health Regulations (2005) Report of the Review Committee on the Functioning of the International Health Regulations (2005) in relation to Pandemic (H1N1) 2009. May 5, 2011. http://apps.who.int/gb/ebwha/pdf_files/WHA64/A64_10-en.pdf (accessed Sept 2, 2014).

13 Institute for Health Metrics and Evaluation, University of Washington. Financing Global Health 2014: transition in an age of austerity. Seattle, WA: Institute for Health Metrics and Evaluation, 2014. http://www.healthdata. org/sites/default/files/files/policy_report/2014/FGH2013/IHME_FGH2013 Full_Report.pdf (accessed Sept 3, 2014)

14 Sridhar D, Gostin LO. Reforming the World Health Organization. JAMA 2011; 305: 1585-86.

15 Gostin LO. Global health law. Cambridge, MA: Harvard University Press, 2014. 